\title{
PENGGUNAAN MEDIA POWER POINT DALAM PEMBELAJARAN MATEMATIKA DAN PENGARUHNYA TERHADAP PRESTASI BELAJAR SISWA
}

\author{
Nurhayati $^{1}$, Yasir Arafat ${ }^{2}$, Yessi Fitriani $^{3}$ \\ Mahasiswa Universitas PGRI' ${ }^{1}$, Dosen Universitas PGRI ${ }^{2}$, \\ Dosen Universitas PGRI ${ }^{3}$ \\ Jalan Jenderal Ahmad Yani Lorong Gotong Royong No. 9/10 Palembang \\ Sur-el: nurhayati13sutarno@gmail.com ${ }^{1}$,yasir_arafat14@yahoo.com², \\ yessifitriani54@yahoo.com ${ }^{3}$
}

Article info

Article history:

Received:15-04-2020

Revised :03-05-2020

Accepted:16-05-2020

Keywords:

Power Point Learning

Media, Mathematic,

Learning

Achievement

Kata Kunci:

Media Pembelajaran

Powerpoint,

Matematika, Prestasi

Belajar

\begin{abstract}
A B S T R A C T
This research aims to determine the effect of using powerpoint media in mathematics learning on student achievement in Madrasah Tsanawiyah Ogan Ilir. This research uses quantitative methods with quasi experimental research types. The population of the study was 221 people, students of class VIII at MTs Negeri 2 Tanjung Raja, Ogan Ilir District. The number of research samples were 72 people. The sampling technique in this study is a nonprobability sampling technique with a type of purposive sampling technique. Data collection techniques using the test model, namely pretest and posttest in the experimental class and the control class. Data were analyzed using simple linear regression analysis analysis techniques. The results showed that there was a significant influence on the use of powerpoint learning media in mathematics learning on student achievement in MTs Negeri 2 Tanjung Raja, Ogan Ilir District.
\end{abstract}

Penelitian ini bertujuan untuk mengetahui pengaruh penggunaan media powerpoint dalam pembelajaran matematika terhadap prestasi belajar siswa di Madrasah Tsanawiyah Ogan Ilir. Penelitian ini menggunakan metode kuantitatif dengan jenis penelitian eksperimen semu. Populasi penelitian sebanyak 221 orang yaitu siswa kelas VIII di MTs Negeri 2 Tanjung Raja Kabupaten Ogan Ilir. Jumlah sampel penelitian sebanyak 72 orang. Teknik pengambilan sampel dalam penelitian ini adalah teknik nonprobability sampling dengan jenis teknik purposive sampling. Teknik pengumpulan data menggunakan model tes, yaitu pretes dan postes pada kelas eksperimen dan kelas kontrol. Data dianalisis menggunakan teknik analisis uji regresi linier sedarhana. Hasil Penelitian menunjukan bahwa ada pengaruh signifikan penggunaan media pembelajaran powerpoint dalam pembelajaran matematika terhadap prestasi belajar siswa di MTs Negeri 2 Tanjung Raja Kabupaten Ogan Ilir. 


\section{JURNAL ILMIAH \\ BINA EDUKASI \\ ISSN 1979-8598E-ISSN: 2655-8378 \\ http://journal.binadarma.ac.id/index.php/jurnalbinaedukasi \\ Vol. 13, No. 1, Juni 2020, 75 - 87}

\section{PENDAHULUAN}

Pada periode kedua pemerintahan Presiden Joko Widodo, visi dan misi yang diusung adalah Indonesia Maju.Maju dalam semua aspek kehidupan berbangsa dan bernegara. Kemajuan suatu bangsa tidak terlepas dari kualitas sumber daya manusia yang dimiliki bangsa tersebut. Dalam rangka menciptakan sumber daya manusia yang unggul, salah satu sektor yang dianggap dominan dan paling penting adalah pendidikan. Kementerian Pendidikan dan Kebudayaan Republik Indonesia berencana merombak total sistem pendidikan di Indonesia, salah satu kebijakan yang paling kontroversial adalah penghapusan sistem ujian akhir nasional di semua tingkat pendidkan. Istilah yang diangkat Mendikbud adalah kemerdekaan belajar, kemerdekaan dunia pendidikan.

Proses pendidikan adalah sebuah upaya perubahan ke arah yang lebih baik. Proses pembelajaran sebagai sebuah komponen, merupakan sebuah kegiatan edukatif berupa interaksi yang terjadi antara guru dengan siswa dan diarahkan untuk mencapai tujuan tertentu. Proses pendidikan ini harus selalu dicermati dan diperbaiki untuk meningkatkan mutu pendidikan. Guru sebagai pimpinan dan penanggung jawab dalam pengelolaan kelas sangat menentukan kualitas pembelajaran. Kreativitas seorang guru harus dapat mengubah strategi belajar mengajar menjadi lebih bermakna dan mampu mengembangkan semua dimensi seperti watak, kepribadian, intelektual, emosional dan sosial siswa (Permatasari, 2014).

Peran teknologi informasi dalam kehidupan manusia saat ini sangat besar. Peran tersebut meliputi berbagai bidang yang salah satunya adalah bidangpendidikan. Pendidikan memegang peranan penting dalam kehidupan manusia. Hal itu disebabkan pendidikan menjadi salah satu cara yang dapat digunakan untuk meningkatkan sumber daya manusia (Buntoro, dkk., 2018). Teknologi komunikasi dapat membawa seorang individu melintasi batas ruang dan waktu serta mendapatkan informasi melalui internet yang tidak didapat sebelumnya. Penggunaan internet telah merambah ke berbagai kehidupan, baik di bidang sosial, budaya, ekonomi, kesehatan, politik, hiburan maupun pendidikan. Namun sedemikian maju teknologi yang masuk ke sektor pendidikan tidak dapat digunakan secara maksimal oleh guru maupun siswa. Penggunaan teknologi informasi tersebut hanya sebatas menjadi alternatif kedua untuk mencari sumber belajar (Iguna, 2017).

Proses belajar dan mengajar di kelas, interaksi antara guru dengan siswa dewasa ini tidak terlepas dari penggunaan teknologi. Begitu juga semestinya dalam proses belajar mengajar di kelas guru seharusnya berbasis teknologi informasi, misalnya dalam menggunakan media pembelajaran. Media pembelajaran merupakan salah satu komponen pendukung keberhasilan 


\section{JURNAL ILMIAH \\ BINA EDUKASI \\ ISSN 1979-8598E-ISSN: 2655-8378 \\ http://journal.binadarma.ac.id/index.php/jurnalbinaedukasi \\ Vol. 13, No. 1, Juni 2020, 75 - 87}

proses belajar mengajar.Media pembelajaran yang digunakan dalam kegiatan pembelajaran dapat mempengaruhi efektivitas pembelajaran.

Pada mulanya, media pembelajaran hanya berfungsi sebagai alat bantu guru untuk mengajar yang digunakan adalah alat bantu visual. Sekitar pertengahan abad ke-20 usaha pemanfaatan visual dilengkapi dengan digunakannya alat audio, sehingga lahirnya alat bantu audio-visual. Sejalan dengan perkembangan ilmu pengetahuan dan teknologi (IPTEK), khususnya dalam bidang pendidikan, saat ini penggunaan alat bantu atau media pembelajaran menjadi semakin luas dan interaktif, seperti adanya komputer dan internet (Brown dikutip melalui Fatimah, 2016).

Selama kegiatan belajar mengajar, dibutuhkan adanya interaksi antara guru dan siswa, agar siswa dapat menyerap materi pelajaran dengan optimal. Sebagai tenaga pengajar dan pendidik yang secara langsung terlibat dalam proses belajar mengajar, guru memegang peran penting dalam mengarahkan siswa mencapai hasil belajar yang maksimal. Salah satu kemampuan yang diharapkan dikuasai oleh guru matematika adalah bagaimana mengajarkan konsep matematika dengan baik. Hal ini dapat didukung dengan pemilihan media pembelajaran yang relevan dengan kompetensi dasar (Srimaya, 2017).

Komputer termasuk salah satu media pembelajaran. Pengunaan komputer dalam pembelajaran merupakan aplikasi teknologi dalam pendidikan. Pada dasarnya teknologi dapat menunjang proses pencapaian tujuan pendidikan. Pemanfaatan media pembelajaran dengan memanfaatkan program aplikasi Microsof dilakukan dengan mengemas materi ajar secara menarik, singkat, padat dan efektif. memiliki fasilitas custom animation yang sangat lengkap (Srimaya, 2017). Microsoft merupakan sebuah software yang dibuat dan dikembangkan oleh perusahaan Microsoft, dan merupakan salah satu program berbasis multi media. Di dalam komputer, biasanya program ini sudah dikelompokkan dalam program Microsoft Office. Program ini dirancang khusus untuk menyampaikan presentasi, baik yang diselenggarakan oleh perusahaan, pemerintahan, pendidikan, maupun perorangan, dengan berbagai fitur menu yang mampu menjadikannya sebagai media komunikasi yang menarik. Microsoft powerpoint adalah program aplikasi untuk membuat atau mengolah data presentasi. Data presentasi yang dibuat dapat berupa teks, tabel, grafik, gambar, bagan organisasi, dan sebagainya (Gumawang, 2007). Powerpoint merupakan salah satu sarana yang populer karena kemudahan dan kelengkapan fiturfiturnya sangat mendukung dalam pembuatan sebuah presentasi yang baik. Dengan program ini, dapat menjelaskan ide atau gagasan kepada orang lain seperti guru, teman-teman, atau orang tua secara efektif sehingga materi yang kita sampaikan akan lebih jelas, menarik, mudah dipahami dan praktis. Oleh karena itu program ini dapat memberikan gambar dan warna yang menarik pada lembar presentasi, serta penyusunnya dengan rapi (Alfian, 2010). 


\section{JURNAL ILMIAH \\ BINA EDUKASI \\ ISSN 1979-8598E-ISSN: 2655-8378 \\ http://journal.binadarma.ac.id/index.php/jurnalbinaedukasi \\ Vol. 13, No. 1, Juni 2020, 75 - 87}

Penggunaan media pembelajaran yang tepat dalam proses belajar dan mengajar dipercaya akan meningkatakan prestasi belajar siswa. Nasution (2006), Prestasi belajar merupakan kesempurnaan yang dicapai seseorang dalam berpikir, merasa dan berbuat. Prestasi belajar dikatakan sempurna apabila memenuhi tiga aspek yakni: kognitif, afektif, psikomotorik, sebaliknya dikatakan prestasi kurang memuaskan jika seseorang belum mampu memenuhi target dalam ketiga kriteria tersebut. Prestasi merupakan keberhasilan dalam proses belajar mengajar yang telah ditempuh siswa, bertujuan untuk memperoleh atau mengembangkan ilmu pengetahuan. Prestasi ini dituangkan dengan nilai atau angka yang diberikan oleh guru kepada siswa.Seringkali dijumpai bahwa rata-rata nilai terendah yang diperoleh siswa dalam satu kelas adalah nilai mata pelajaran matematika.

Matematika merupakan salah satu komponen dari serangkaian mata pelajaran yang mempunyai peranan penting dalam pendidikan. Matematika merupakan salah satu bidang studi yang mendukung perkembangan ilmu pengetahuan dan teknologi. Namun sampai saat ini masih banyak siswa yang merasa matematika sebagai mata pelajaran yang sulit, tidak menyenangkan, bahkan momok yang menakutkan. Hal tersebut membuat siswa merasa kesulitan dalam mempelajarinya.Ada banyak faktor yang membuat siswa merasa matematika adalah pelajaran yang tersulit. Salah satu faktor yang menjadikan matematika bukan pelajaran yang menyenangkan adalah cara guru dalam menyampaikan materi pelajaran. Mengajar semestinya tidak hanya sebatas menyampaikan materi ajar, akan tetapi mengajar merupakan seluruh rangkaian kegiatan dan tindakan yang telah diupayakan oleh guru dalam proses belajar dan mengajar sehingga tujuan yang telah dirumuskan dapat tercapai (Solihatin, 2012).

Kemampuan pemecahan masalah matematis merupakan kemampuan yang esensial untuk dikembangkan pada siswa sekolah menengah. Pentingnya menguasai kemampuan pemecahan masalah matematis di atas termuat dalam Permendiknas Nomor 20 tahun 2006 tentang standar isi, disebutkan bahwa pembelajaran matematika bertujuan supaya siswa memiliki kemampuan, antara lain: siswa memiliki kemampuan mengkomunikasikan gagasan atau ide matematika dengan menggunakan simbol, tabel, diagram, dan atau media lain untuk memperjelas keadaan suatu masalah, memahami masalah, merancang model matematika, menyelesaikan model matematika dan menafsirkan solusi yang diperoleh, serta memiliki sikap ulet dan percaya diri dalam pemecahan masalah (Dahlia, dkk., 2015).

Berbagai cara dilakukan guru untuk membuat pelajaran matematika menjadi menarik dan menyenagkan. Salah satu cara yang dapat diupayakan adalah menggunakan media pembelajaran yang dapat menarik minat siswa. Salah satu media pembelajaran yang dapat digunakan adalah powerpoint. Program microsoft power point merupakan salah satu diantara sekian banyak media presentasi. Program ini cukup populer karena sebagian besar (yang salah satunya memuat aplikasi 


\section{JURNAL ILMIAH \\ BINA EDUKASI \\ ISSN 1979-8598E-ISSN: 2655-8378 \\ http://journal.binadarma.ac.id/index.php/jurnalbinaedukasi \\ Vol. 13, No. 1, Juni 2020, 75 - 87}

power point) sehingga seseorang tinggal menggunakannya komputer yang ada di sekolah-sekolah sudah diinstall microsoft office.

Berdasarkan wawancara awal yang dilakukan terhadap guru-guru di Madrasah Tsanawiyah (MTS) Negeri 02 Tanjung Raja Kabupaten Ogan Ilir bahwa dalam proses pembelajaran matematika masih sedikit guru yang melibatkan siswa dalam proses pembelajaran dan masih terbatasnya media yang digunakan sehingga membuat siswa kesulitan dalam menggunakan rumus-rumus matematika yang berdampak pada hasil ulangan siswa yang masih banyak belum mencapai KKM. Berdasarkan wawancara awal peneliti terhadap beberapa orang siswa di MTS Negeri 02 Tanjung Raja Kabupaten Ogan Ilir, didapatkan realita bahwa siswa kurang atusias dalam belajar dan kurang semangat disebabkan antara lain karena guru mengajar di kelas terkesan monoton, media pembelajaran yang digunakan kurang menarik, bahkan banyak guru yang mengajar hanya sebatas ceramah, tidak memanfaatkan media pembelajaran yang ada. Belum ada pemanfaatan teknologi dalam proses belajar mengajar di kelas.

Berdasarkan pengamatan peneliti bahwa guru-guru di MTS Negeri 02 Tanjung Raja Kabupaten Ogan Ilir dalam proses belajar mengajar di kelas masih dilaksanakan secara konvensional, metode yang diterapkan kebanyakan masih metode ceramah, media pembelajaran yang digunakan masih sebatas papan tulis. Hal tersebut membuat proses belajar di kelas masih terkesan monoton dan membosankan. Oleh karena itu maka peneliti melakukan penggunaan media pembelajaran berbasis pemanfaatan teknologi untuk kemampuan prestasi siswa pada mata pelajaran matematika.

Berdasarkan hasil penelitian lain, yaitu penelitian Ario (2017) hasil penelitiannya menyatakan adanya peningkatan kemampuan penalaran matematika siswa berbasis masalah lebih tinggi dibandingkan peningkatan kemampuan penalaran matematis siswa yang mendapatkan pembelajaran penemuan terbimbing. Asfar dan Aspikal (2017) menyatakan bahwa dengan penerapan model pembelajaran dapat meningkatkan penalaran matematika siswa serta memberikan respon positif. Sudiantini dan Shinta (2018) menyatakan bahwa terdapat pengaruh signifikan media pembelajaran terhadap kemampuan berpikir kreatif dan penalaran matematis siswa.

Berdasarkan uraian latar belakang masalah di atas, maka dapat diidentifikasi beberapa permasalahan, antara lain: (1)Proses belajar dan mengajar di dalam kelas belum berjalan secara optimal dikarenakan interaksi antara guru dan siswa belum terjadi sebagaimana mestinya; (2) Guru masih melakukan pembelajaran matematika dengan teks book oriented, pola mengajar guru masih konvensional dengan metode ceramah, monoton sehingga membuat siswa menjadi bosan; (3) Guru dalam proses belajar dan mengajar di kelas belum berbasis teknologi. Pemanfaatan media pembelajaran yang belum dioptimalkan, media pembelajaran yang digunakan kurang menarik, karena belum memanfaatkan teknologi sebagaimana perkembangan yang terjadi saat 


\section{JURNAL ILMIAH \\ BINA EDUKASI \\ ISSN 1979-8598E-ISSN: 2655-8378 \\ http://journal.binadarma.ac.id/index.php/jurnalbinaedukasi \\ Vol. 13, No. 1, Juni 2020, 75 - 87}

ini; (4) Sebagian siswa masih menganggap mata pelajaran matematika adalah mata pelajaran yang kurang menarik dan sulit. Nilai rata-rata mata pelajaran matematika yang diperoleh siswa kategori rendah dan beberapa siswa masih tidak mencapai nilai KKM. Dan yang menjadi tujuan dalam penelitian ini adalah untuk mengetahuiada tidaknya pengaruhpenggunaan media power point dalam pembelajaran matematika terhadap prestasi belajar siswa di MTs Negeri 2 Tanjung Raja Kabupaten Ogan Ilir.

\section{METODOLOGI PENELITIAN}

\subsection{Jenis/Desain Penelitian}

Penelitian ini menggunaan metode penelitian kuantitatif, dengan rancangan penelitian berbentuk studi pengaruh.Desain penelitian yang digunakan dalam penelitian ini adalah quasi eksperimental design.Desain yang digunakan adalah Nonequivalent Control Group Design, yaitu desain penelitian berupa kuasi eksperimen dengan melibatkan perbedaan pretest dan posttest antara kelas eksperimen dan kelas kontrol yang dipilih.Ada dua kelas yang dipilih dalam penelitian, yaitu kelas eksperimen dan kelas kontrol. Kelas eksperimen dan kelas kontrol mendapatkan perlakuan pembelajaran yang sama dari segi tujuan, isi, bahan pembelajaran dan waktu belajar. Perbedaan perlakuan diantara kelas eksperimen dengan kelas kontrol adalah pada kelas eksperimen peneliti memanfaatkan media pembelajaran power point pada saat menyampaikan materi di kelas, sedangkan di kelas kontrol peneliti tidak memanfaat media pembelajaran power point saat menyampaikan materi di kelas, pada kelas kontrol ini peneliti menyampaikan materi secara konvensional, media yang digunakan hanya papan tulis dan spidol.

\subsection{Populasi Dan Sampel}

Sugiyono (2013) populasi adalah wilayah generalisasi yang terdiri atas objek atau subjek yang memiliki kualitas dan karakteristik tertentu dan ditetapkan oleh peneliti untuk dipelajari kemudian ditarik kesimpulannya. Berdasarkan pengerian tersebut di atas, dapat disimpulkan bahwa populasi adalah objek/subjek yang ada pada suatu wilayah dan memiliki karakteristik tertentu untuk dilakukan penelitian. Populasi dari penelitian ini adalah siswa kelas VIII di MTs Negeri 2 Tanjung Raja yang berjumlah sebanyak 221 orang siswa, terdiri dari 103 siswa laki-laki dan 118 siswa perempuan tersebar di 6 kelas.

Sugiyono (2013) sampel adalah bagian dari jumlah dan karakteristik yang dimiliki oleh populasi tersebut. Sedangkan Arikunto (2010), sampel atau contoh adalah sebagian atau wakil populasi yang diteliti. Sehingga dapat disimpulkasn bahwa sampel adalah jumlah atau karakteristik yang mewakili populasi yang diteliti. Pada penelitian ini sampel yang diambil menggunakan teknik sampling nonprobability sampling dengan jenis teknik sampling purposive. Hikmawati (2017) teknik sampling purposive dilakukan dengan cara mengambil subjek bukan 


\section{JURNAL ILMIAH \\ BINA EDUKASI \\ ISSN 1979-8598E-ISSN: 2655-8378 \\ http://journal.binadarma.ac.id/index.php/jurnalbinaedukasi \\ Vol. 13, No. 1, Juni 2020, 75 - 87}

didasarkan atas strata, random atau daerah tetapi didasarkan atas adanya tujuan tertentu.Dalam penelitian ini yang dijadikan sampel penelitian, yaitu kelas VIII-4 dan kelas VIII-5, maka kelas yang terpilih sebagai kelas eksperimen adalah kelas VIII-4 dengan jumlah siswa 36 orang dan kelas yang terpilih sebagai kelas kontrol adalah kelas VIII-5 dengan jumlah siswa 36 orang.

\subsection{Definisi Operasional Variabel}

Media Pembelajaran Power Point (X) : Media pembelajran power point dalam penelitian ini disusun untuk media presentasi/paparan materi persamaan linier dua variable mata pelajaran matematika. Kelas yang diberikan perlakuan media power point adalah kelas VIII-4 sebagai kelas eksperimen dengan menggunakan langkah-langkah tertentu hingga menuju kesimpulan. Langkah-langkah pelaksanaan pembelajaran dengan menggunakan media power point yang dilakukan dalam penelitian ini sama dengan langkah-langkah pembelajaran yang ada dalam buku siswa, akan tetapi media yang digunakan untuk menyampaikan materi pembelajaran adalah media power point.

Prestasi Belajar (Y): Prestasi belajar ini dapat dilihat secara nyata berupa skor atau nilai setelah mengerjakan suatu tes. Tes yang digunakan untuk menggunakan prestasi belajar merupakan suatu alat untuk mengukur aspek-aspek tertentu dari siswa misalnya pengetahuan, pemahaman atau aplikasi suatu konsep. Prestasi belajar pada penelitian ini adalah hasil pretest dan postest yang diperoleh siswa pada mata pelajaran matematika.

\subsection{Teknik Analisa Data}

Teknik analisis data dalam penelitian menggunakan teknik analisis deskriptif data merupakan statistik deskriptif yang berfungsi untuk mendeskripsikan atau memberi gambaran terhadap objek yang diteliti melalui data sampel sebagaimana adanya. Menurut Sugiyono (2013) bahwa statistik deskriptif adalah statistik yang digunakan untuk menganalisis data yang sudah terkumpul sebagaimana adanya tanpa bermaksud membuat kesimpulan yang berlaku untuk umum atau generalisai. Data dari hasil tes dalam penelitian ini merupakan data kuantitatif yang akan dianalisis secara deskriptif melalui perhitungan penyebaran data melalui perhitungan ratarata, standar deviasi dan persentase. Data prestasi siswa berupa data hajil pretest dan posttest. Data dianalisis dengan uji regresi linier sedarhana.

\section{HASIL DAN PEMBAHASAN}

\subsection{Hasil}

\subsubsection{Hasil Uji Validitas}

Arikunto (2010), validitas adalah ukuran yang menunjukkan tingkat kevalidan atau kesahihan suatu instrument. Validitas sangat erat kaitannya dengan tujuan pengukuran suatu penelitian. Validitas merupakan suatu ukuran yang menunjukan tingkat-tingkat kevalidan atau 


\section{JURNAL ILMIAH \\ BINA EDUKASI \\ ISSN 1979-8598E-ISSN: 2655-8378 \\ http://journal.binadarma.ac.id/index.php/jurnalbinaedukasi \\ Vol. 13, No. 1, Juni 2020, 75 - 87}

kesalahan suatu instrument. Suatu instrumen yang valid mempunyai validitas yang tinggi. Sebaliknya, instrumen yang kurang valid berarti memiliki validitas rendah (Arikunto, 2010). Cara untuk mengukur validitas dapat menggunakan rumus Korelasi Product Momentuntuk mengetahui nilai $\mathrm{r}_{\mathrm{xy}}$. Kemudian dari hasil perhitungan $\mathrm{r}_{\mathrm{xy}}$ yang didapat dibandingkan dengan tabel rproduct moment dengan signifikansi sebesar 5\%, apabila $\boldsymbol{r}_{\text {hitung }}>\mathrm{r}_{\text {tabel }}$ maka alat ukur tersebut dinyatakan valid, dan sebaliknya apabila $\boldsymbol{r}_{\text {hitung }}>\mathrm{r}_{\text {tabel }}$ maka alat ukur tersebut dinyatakan tidak valid.

Pada penelitian ini dapat disimpulkan bahwa kelima soal pretest memiliki $r_{\text {hitung }}>r_{\text {tabel }}$ sehingga soal pretest dinyatakan valid dan dapat digunakan sebagai alat ukur. Item soal nomor 1 memiliki nilai $\mathrm{r}_{\mathrm{xy}}$ sebesar 0,715 maka tingkat kevaliditasnya kategori tinggi. Item soal nomor 2 memiliki nilai $\mathrm{r}_{\mathrm{xy}}$ sebesar 0,740 maka tingkat kevaliditasnya kategori tinggi. Item soal nomor 3 memiliki nilai $r_{x y}$ sebesar 0,824 maka tingkat kevaliditasnya kategori sangat tinggi. Item soal nomor 4 memiliki nilai $r_{x y}$ sebesar 0,887 maka tingkat kevaliditasnya kategori sangat tinggi. Sedangkan Item soal nomor 5 memiliki nilai $r_{x y}$ sebesar 0,704 maka tingkat kevaliditasnya kategori tinggi.

Sedangkan hasil perhitungan uji validitas soal-soal postesjuga memiliki $\mathbf{r}_{\text {hitung }}>\mathrm{r}_{\text {tabel }}$ sehingga soal posttest dinyatakan valid dan dapat digunakan sebagai alat ukur.Item soal nomor 1 memiliki nilai $\mathrm{r}_{\mathrm{xy}}$ sebesar 0,677 maka tingkat kevaliditasnya kategori tinggi. Item soal nomor 2 memiliki nilai $\mathrm{r}_{\mathrm{xy}}$ sebesar 0,733 maka tingkat kevaliditasnya kategori tinggi. Item soal nomor 3 memiliki nilai $\mathrm{r}_{\mathrm{xy}}$ sebesar 0,659 maka tingkat kevaliditasnya kategori tinggi. Item soal nomor 4 memiliki nilai $r_{x y}$ sebesar 0,677 maka tingkat kevaliditasnya kategori tinggi. Dan Item soal nomor 5 memiliki nilai $\mathrm{r}_{\mathrm{xy}}$ sebesar 0,733 maka tingkat kevaliditasnya kategori tinggi.

\subsubsection{Hasil Uji Reliabilitas}

Selain uji tingkat validitas, tes yang baik dan telah teruji validitasnya, harus diukur tingkat reriabilitasnya. Reliabilitas adalah ketepatan hasil tes apabila diteskan kepada subjek yang sama dalam waktu yang berbeda. Instrumen yang dikatakan reliabel adalah instrumen yang bila digunakan beberapa kali untuk mengukur objek yang sama, akan menghasilkan data yang sama. Arikunto (2010), untuk mengetahui reliabilitas alat ukur digunakan rumus Alpha untuk mengetahui nilai $\mathbf{r}_{11}$ (koofisien reliabilitas). Hasil $\mathbf{r}_{11}$ yang didapat dari perhitungan dibandingkan dengan harga $r$ product moment dengan signifikansi sebesar 5\%, apabila $\mathrm{r}_{\text {hitung }}>\mathrm{r}_{\text {tabel }}$ maka alat ukur tersebut dinyatakan reliabel, dan sebaliknya apabila $\boldsymbol{r}_{\text {hitung }}>\mathrm{r}_{\text {tabel }}$ maka alat ukur tersebut dinyatakan tidak reliabel.

Pada penelitian ini soal pretest mendapat nilai $r_{\text {tabel }}$ dengan $\alpha=5 \%$ dan $\mathrm{N}=10$, maka $\mathrm{r}_{\text {tabel }}$ sebesar 0,632 . Soal pretes hasilnyar ${ }_{\text {hitung }}>\mathrm{r}_{\text {tabel }}(0,865>0,632)$ berarti soal pretes ini dinyatakan reliabel. Nilai $\mathbf{r}_{11}$ sebesar 0,865 maka tingkat reliabilitas soal pretest kategori sangat tinggi. 


\section{JURNAL ILMIAH \\ BINA EDUKASI \\ ISSN 1979-8598E-ISSN: 2655-8378 \\ http://journal.binadarma.ac.id/index.php/jurnalbinaedukasi \\ Vol. 13, No. 1, Juni 2020, 75 - 87}

Sedangkan untuk soal posttest hasilnya $r_{\text {hitung }}>r_{\text {tabel }}(1,006>0,632)$ berarti soal postes ini dinyatakan reliabel. Nilai $\mathrm{r}_{11}$ sebesar 1,006 maka tingkat reliabilitas soal postes kategori sangat tinggi.

\subsubsection{Hasil Pretes pada Masing-Masing Kelas}

Setelah dilaksanakan pretes pada masing-masing kelas, baik di kelas eksperimen maupun di kelas kontrol, maka didapatlah hasil nilai pretesdengan nilai tertinggi yang diperoleh siswa di kelas eksperimen sebesar 82,00 dan nilai terendah sebesar 35,00 dengan nilai rata-rata kelas eksperimen sebesar 56,81. Sedangkan nilai pretes tertinggi yang diperoleh siswa di kelas kontrol sebesar 80,00 dan nilai terendah sebesar 35,00 dengan nilai rata-rata kelas kontrol sebesar 56,83. Jumlah siswa yang memperoleh nilai pretes kategori sangat baik antara kelas eksperimen dengan kelas kontrol tidak jauh berbeda. Di kelas eksperimen dan kelas kontrol tidak ada siswa yang memperoleh nilai kategori sangat baik. Untuk nilai pretes kategori baik, di kelas eksperimen sebanyak 5 orang siswa yang memperoleh nilai kategori baik, sedangkan di kelas kontrol sebanyak 3 orang siswa. Untuk nilai pretes kategori cukup, di kelas eksperimen sebanyak 3 orang siswa yang memperoleh nilai kategori cukup, sedangkan di kelas kontrol sebanyak 4 orang siswa. Untuk nilai pretes kategori kurang, di kelas eksperimen ada 7 orang siswa yang memperoleh nilai kategori kurang, sedangkan di kelas kontrol sebanyak 8 orang siswa. Sedangkan untuk nilai pretes kategori sangat kurang, di kelas eksperimen dan kelas kontrol sama yaitu ada 21 orang siswa yang memperoleh nilai kategori sangat kurang.

\subsubsection{Hasil Postes pada Masing-Masing Kelas}

Setelah dilaksanakan postes pada masing-masing kelas, baik di kelas eksperimen maupun di kelas kontrol, maka didapatlah hasil nilai postesdengan nilai tertinggi yang diperoleh siswa di kelas eksperimen sebesar 95,00 dan nilai terendah sebesar 60,00 dengan nilai rata-rata kelas eksperimen sebesar 79,94. Sedangkan nilai postes tertinggi yang diperoleh siswa di kelas kontrol sebesar 85,00 dan nilai terendah sebesar 50,00 dengan nilai rata-rata kelas kontrol sebesar 62,83. jumlah siswa yang memperoleh nilai postes kategori sangat baik di kelas eksperimen sebanyak 20 orang siswa, sedangkan di kelas kontrol hanya 1 orang siswa. Untuk nilai postes kategori baik, di kelas eksperimen sebanyak 5 orang siswa yang memperoleh nilai kategori baik, sedangkan di kelas kontrol sebanyak 6 orang siswa. Untuk nilai posttest kategori cukup, di kelas eksperimen sebanyak 5 orang siswa yang memperoleh nilai kategori cukup, sedangkan di kelas kontrol sebanyak 2 orang siswa. Untuk nilai posteskategori kurang, di kelas eksperimen ada 5 orang siswa yang memperoleh nilai kategori kurang, sedangkan di kelas kontrol sebanyak 10 orang siswa. Sedangkan untuk nilai posteskategori sangat kurang, di kelas eksperimen sebanyak 1 orang siswa, sedangkan di kelas kontrol ada 17 orang siswa yang memperoleh nilai kategori sangat kurang. 


\section{JURNAL ILMIAH \\ BINA EDUKASI \\ ISSN 1979-8598E-ISSN: 2655-8378 \\ http://journal.binadarma.ac.id/index.php/jurnalbinaedukasi \\ Vol. 13, No. 1, Juni 2020, 75 - 87}

\subsubsection{Hasil Uji Hipotesis}

Uji hipotesis dalam penelitian ini menggunakan uji regresi linier sedarhana yang bertujuan untuk mengetahui ada dan tidaknya pengaruh penggunaan media power point dalam pembelajaran matematika terhadap prestasi belajar siswa di MTs Negeri 2 Tanjung Raja Kabupaten Ogan Ilir. Uji regresi linier sedarhana pada penelitian ini dianalisis mengunakan program SPSS-19. Hipotesis $\left(\mathrm{H}_{\mathrm{a}}\right)$ menyatakan bahwa ada pengaruh penggunaan media power point dalam pembelajaran matematika terhadap prestasi belajar siswa MTs Negeri 2 Tanjung Raja Ogan Ilir. Hal tersebut dapat dibuktikan dengan data pada tabel di atas bahwa nilai thitung sebesar 9,619 dengan $\mathrm{dk}=72$ dan taraf signifikan 5\%, maka diperoleh $t_{\text {tabel }}$ sebesar 2,34. Dengan demikian $t_{\text {hitung }}>t_{\text {tabel }}(9,619>2,34)$, maka dapat disimpulkan bahwa hipotesis $\left(\mathrm{H}_{\mathrm{a}}\right)$ diterima/terbukti. Ini berarti bahwa ada pengaruh signifikan penggunaan media power point dalam pembelajaran matematika terhadap prestasi belajar siswa MTs Negeri 2 Tanjung Raja Kabupaten Ogan Ilir.

\subsection{Pembahasan}

Berdasarkan hasil penelitian di atas menunjukan bahwa penggunaan media power point efektif untuk meningkatkan prestasi belajar siswa. Sesuai dengan pendapat Brown (dalam Fatimah, 2016) bahwa media pembelajaran yang digunakan dalam kegiatan pembelajaran dapat mempengaruhi efektivitas pembelajaran. Penggunaan media pembelajaran yang tepat dalam proses belajar dan mengajar dipercaya akan meningkatakan prestasi belajar siswa (Nasution, 2006).

Perolehan nilai rata-rata pretes di kelas eksperimen sebesar 56,81 sedangkan perolehan nilai rata-rata di kelas kontrol sebesar 56,83. Artinya tidak ada perbedaan yang signifikan antara nilai pretes di kelas eksperimen dengan nilai pretes di kelas kontrol. Hal tersebut menunjukan bahwa tidak ada perbedaan yang signifikan prestasi belajar siswa di kelas eksperimen dengan prestasi belajar siswa di kelas kontrol sebelum diterapkan pelaksanaan penggunaan media pembelajaran power point.

Sedangkan perolehan nilai rata-rata postes di kelas eksperimen sebesar 79,94 dan perolehan nilai rata-rata postes di kelas kontrol sebesar 62,83. Artinya ada perbedaan yang signifikan antara nilai postes di kelas eksperimen dengan nilai postes di kelas kontrol. Berdasarkan perolehan nilai rata-rata prestasi belajar matematika siswa kelas eksperimen lebih besar daripada perolehan nilai rata-rata prestasi belajar matematika siswa kelas kontrol $\left(\mu_{1}>\mu_{2}\right)$. Hal tersebut menunjukan bahwa penggunaan media pembelajaran power point dalam pembelajaran matematika dapat meningkatkan secara signifikan prestasi belajar matematika siswa di MTs Negeri 2 Tanjung Raja Ogan Ilir.

Hasil penelitian ini sejalan dengan hasil penelitian yang dilakukan oleh Miftahul Rahman (2018) bahwa terdapat pengaruh yang signifikan media pembelajaran power point terhadap hasil 


\section{JURNAL ILMIAH \\ BINA EDUKASI \\ ISSN 1979-8598E-ISSN: 2655-8378 \\ http://journal.binadarma.ac.id/index.php/jurnalbinaedukasi \\ Vol. 13, No. 1, Juni 2020, 75 - 87}

belajar matematika peserta didik kelas X di SMAN 3 Majene tahun ajaran 2016/2017. Sejalan juga dengan hasil penelitian Dona Fitriani (2017) bahwa penggunaan media pembelajaran power point berpengaruh terhadap peningkatan minat belajar siswa pada mata pelajaran Sejarah kelas $\mathrm{X}$ SMA Gajah Mada Bandar Lampung.

Pada mulanya media pembelajaran hanya berfungsi sebagai alat bantu guru untuk mengajar, alat bantu yang digunakan adalah alat bantu visual. Sekitar pertengahan abad ke-20 usaha pemanfaatan visual dilengkapi dengan digunakannya alat audio, sehingga lahirnya alat bantu audio-visual. Sejalan dengan perkembangan ilmu pengetahuan dan teknologi (IPTEK), khususnya dalam bidang pendidikan, saat ini penggunaan alat bantu atau media pembelajaran menjadi semakin luas dan interaktif, seperti adanya komputer dan internet (Brown dikutip melalui Fatimah, 2016).

Prestasi belajar merupakan kesempurnaan yang dicapai seseorang dalam berfikir, merasa dan berbuat. Prestasi belajar dikatakan sempurna apabila memenuhi tiga aspek yakni: kognitif, afektif, psikomotorik, sebaliknya dikatakan prestasi kurang memuaskan jika seseorang belum mampu memenuhi target dalam ketiga kriteria tersebut. Salah satu media pembelajaran yang popular saat ini adalah media pembelajaran power point. Media power point sudah semakin canggih, fitur-fitur yang ditampilkan semakin menarik, tidak hanya visual, tetapi juga dapat menampilkan audio visual yang makin menarik (Nasution, 2006).

Pelajaran Matematika seringkali dianggap pelajaran yang menakutkan, tidak menarik dan membosankan, apalagi didukung oleh guru pengampu mata pelajaran matematika yang kiler atau kurang menarik bagi siswa. Oleh karena itu guru pengampu mata pelajaran matematika mencari cara untuk membuat pelajaran matematika menjadi menarik dan menyenagkan. Salah satu cara yang dapat diupayakan adalah menggunakan media pembelajaran yang dapat menarik minat siswa. Salah satu media pembelajaran yang dapat digunakan adalah power point. Media power point dapat dikreasi tampilannya semenarik mungkin sesuai dengan kebutuhan materi pelajaran yang sedang dibahas.

Guru hendaknya dapat memanfaatkan media pembelajaran power point dalam menarik minat belajar siswa sehingga prestasi belajar siswa dapat meningkat. Pihak sekolah seharusnya menyediakan sarana dan prasarana belajar yang dapat mendukung peningkatan prestasi belajar siswa. Selain metode mengajar, kurikulum, relasi guru dengan siswa, relasi siswa dengan siswa, disiplin siswa, dan keadaan gedung, maka faktor lain yang mempengaruhi prestasi belajar adalah media pembelajaran yang diterapkan guru. 


\section{JURNAL ILMIAH \\ BINA EDUKASI \\ ISSN 1979-8598E-ISSN: 2655-8378 \\ http://journal.binadarma.ac.id/index.php/jurnalbinaedukasi \\ Vol. 13, No. 1, Juni 2020, 75 - 87}

\section{SIMPULAN}

Berdasarkan analisis hasil penelitian dan pembahasan data melalui pembuktian hipotesis, yaitu pengaruh penggunaan media pembelajaran power point $(\mathrm{X})$ terhadap peningkatan prestasi belajar siswa (Y), maka dapat disimpulkan bahwa ada pengaruh yang signifikan penggunaan media power point dalam pembelajaran matematika terhadap prestasi belajar siswa di MTs Negeri 2 Tanjung Raja Kabupaten Ogan Ilir.Berdasarkan perolehan nilai rata-rata prestasi belajar matematika siswa kelas eksperimen lebih besar daripada perolehan nilai rata-rata prestasi belajar matematika siswa kelas kontrol.Hal tersebut menunjukan bahwa penggunaan media pembelajaran power point dalam pembelajaran matematika dapat meningkatkan secara signifikan prestasi belajar matematika siswa di MTs Negeri 2 Tanjung Raja Ogan Ilir.

Penggunaan media pembelajaran yang tepat dalam proses belajar dan mengajar dipercaya akan meningkatakan prestasi belajar siswa. Guru hendaknya dapat memanfaatkan media pembelajaran power point dalam menarik minat belajar siswa sehingga prestasi belajar siswa dapat meningkat. Pihak sekolah seharusnya menyediakan sarana dan prasarana belajar yang dapat mendukung peningkatan prestasi belajar siswa. Berdasarkan teori dan hasil penelitian yang telah teruji kebenarannya, menyatakan bahwa ada pengaruh yang signifikan penggunaan media powerpoint dalam pembelajaran matematika terhadap peningkatan prestasi belajar matematika siswa, oleh karena itu dengan penggunaan media pembelajaran power point, maka diharapkan prestasi belajar siswa akan semakin meningkat sesuai tujuan pembelajaran di kelas.

\section{DAFTAR PUSTAKA}

Alfian. (2010). Membuat Presentasi Menakjubkan dengan Microsoft Power 2007.Bandung: Mediakita.

Arikunto, Suharsimi. (2010). Dasar-Dasar Evaluasi Pendidikan. Jakarta: PT Rineka Cipta.

Ario, M. (2017). Perbandingan Peningkatan Kemampuan Penalaran Matematis antara Pembelajaran Berbasis Masalah dan Penemuan Terbimbing Ditinjau dari Kemampuan Awal Matematis Siswa. Jurnal Eksakta Pendidikan (JEP), Vol. 1(2), hal. 56-63.

Asfar, A. M., \& Aspikal. (2017). Pengembangan Model Pembelajaran Berbasis Connecting Extending Review (CER) untuk Meningkatkan Kemampuan Penalaran Matematika. Bone : Seminar Nasional Riset Inovatif, hal. 621-630.

Buntoro, G. A., Ariyadi, D., \& Astuti, I. P. (2018). Pemanfaatan E-Learning Quipper School oleh Guru dan Siswa untuk Optimalisasi Pembelajaran di MAN 1 Ponorogo. JPKM, 3(2), hal.157-167.

Dahlia, B., Tandililing, E., \& Suratman, D. (2015). Peningkatan Kemampuan Pemecahan Masalah Matematis Menggunakan Pendekatan Saintifik dan Pendekatan. CTL. Hal.114. 


\section{JURNAL ILMIAH \\ BINA EDUKASI \\ ISSN 1979-8598E-ISSN: 2655-8378 \\ http://journal.binadarma.ac.id/index.php/jurnalbinaedukasi \\ Vol. 13, No. 1, Juni 2020, 75 - 87}

Dona, Fitriani. (2017). Pengaruh Media Pembelajaran Power Point terhadap Minat Belajar Sejarah Siswa Kelas X SMA Gajah Mada Bandar Lampung Tahun Ajaran 2016/2017. https://jurnal.fkip.unila.ac.id/nju/index.php/jurnal/article/view/14329. Diunduh pada tanggal 30 Desember 2019.

Fatimah. (2016). Pengembangan Media Pembelajaran Menggunakan Software Adobe Flash Profesional CS6 Pada Materi Gula Dan Hasil Olahnya Untuk Siswa Kelas X Jasa Boga SMK Negeri 1 Sewon. Jurnal online ePrint@UNY. http//eprints.uny.ic.id . Diunduh pada tanggal 30 November 2019.

Gumawang, A. (2007). Belajar Otodidak Word, Excel, Power Point XP. Bandung: Informatika.

Iguna, S. (2017). Effectiveness of Quipper School and Web Blog Media to Increase Geographic Learning Result at Class XI in MAN of Special Region of Yogyakarta. Hal 468-477.

Nasution. (2006). Berbagai Pendekatan Dalam Proses Belajar Mengajar. Jakarta: Bumi Aksara.

Nirmawati, Tarman Andi Arief. (2018). Pengaruh Penggunaan Media Pembelajaran Power Point Terhadap Minat dan Kemampuan Membaca Siswa pada Mata Pelajaran Bahasa Indonesia Kelas IV. Jurnal Kajian Pendidikan Dasar. Vol. 3. No. 1/2018.

Solihatin, Etin. (2012). Strategi Pembelajaran PPKN. Jakarta: Bumi Aksara.

Srimaya. (2017). Efektivitas Media Pembelajaran Power Point untuk Meningkatkan Motivasi dan Hasil Belajar Biologi Siswa. Biotek, 5(1), hal. 53-68.

Sudiantini, D. \& Shinta, N.D. (2018). Pengaruh Media Pembelajaran Terhadap Kemampuan Berpikir Kreatif dan Penalaran Matematis Siswa. Jurnal Penelitian dan Pembelajaran Matematika, Vol. 11 No. 1. http://jurnal.untirta.ac.id/index.php/JPPM/issue/view/354. Diunduh pada tanggal 30 Desember 2019.

Sugiyono. (2013). Metode Penelitian Kuantitatif-Kualitatif Dan $R \& D$. Bandung: Penerbit Alfabeta.

-. (2013). Statistika untuk Penelitian. Bandung: Penerbit Alfabeta.

Peraturan Menteri Pendidikan Nasional RI No. 22 (2006). Tentang Standar Isi Untuk Satuan Pendidikan Dasar dan Menenagah.

Permatasari, A. A. (2014). The Influence of Powerpoint Multimedia Usage to Increase Students Short Story Writing Skill in Indonesian Language Learning. Jurnal Ilmu Pendidikan, Vol. 1. hal. 19-23 